\title{
ВЕКТОРИ РОЗВИТКУ ПОЗАШКІЛЬНОЇ ОСВІТИ ЯК ОСВІТНІ ТРЕНДИ СУЧАСНОСТІ
}

\author{
За матеріалами проведення Всеукраїнської науково-практичної конференції \\ "Позашкільна освіта у викликах сучасності: досягнення та вектори розвитку», \\ 22 квітня 2021 р., відповідно до плану заходів Начіональної академії педагогічних \\ наук України (присвячено 30-річчю Незалежності України)
}

https://doi.org/10.37472/2707-305X-2021-3-2-17-9

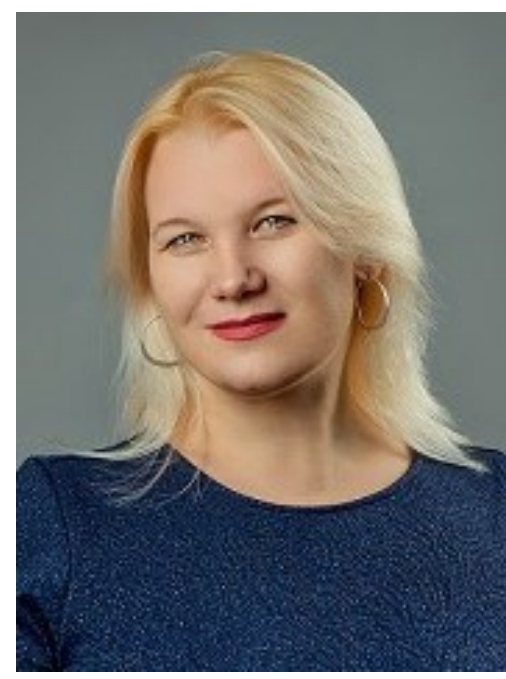

ПРОСІНА

\section{Ольга Володимирівна}

кандидат педагогічних наук, дочент, завідувач кафедри фрілософрії і освіти дорослих Центрального інституту післядипломної освіти ДЗВО «Університет менеджменту освіти», Начіональна академія педагогічних наук України, керівник ГО "Центр освітніх ініціатив "Толока», м. Київ, Україна

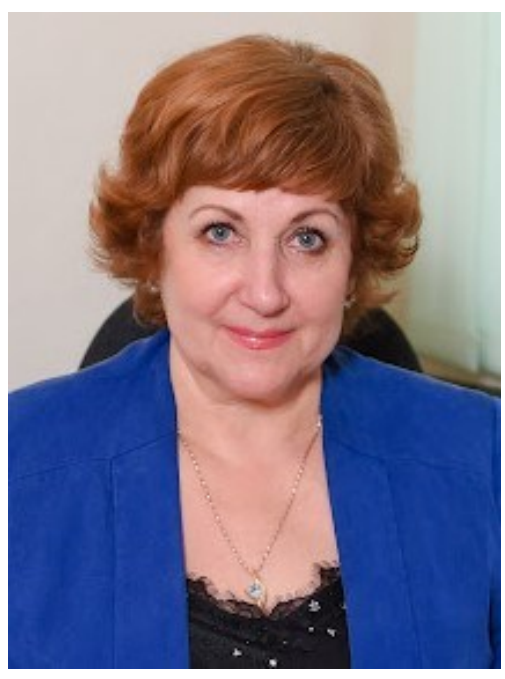

КАСЬЯНОВА

Ольга Володимирівна кандидат педагогічних наук, дочент, заступник директора з наукової роботи Луганського обласного інституту післядипломної педагогічної освіти, м. Севєродонецьк, Україна

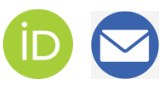

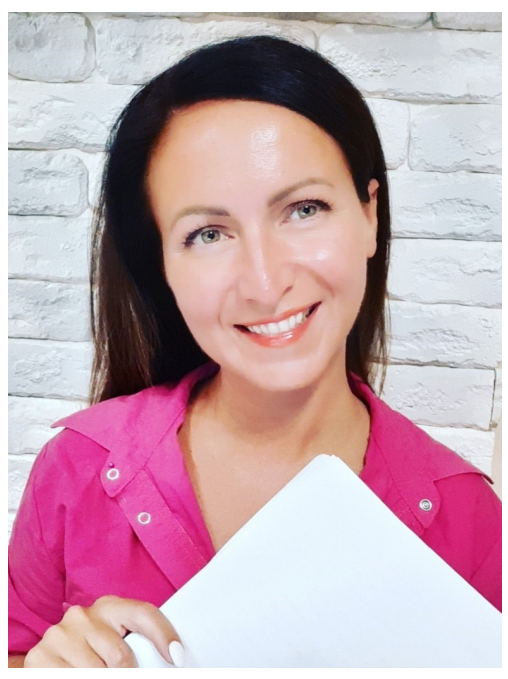

ШBEHb

\section{Ярослава Леонідівна}

кандидат психологічних наук, дочент, дочент кафредри фрілософії і освіти дорослих Центрального інституту післядипломної освіти ДЗВО «Університет менеджменту освіти», Національна академія педагогічних наук України, член Національної психологічної асочіачії, м. Київ, Україна

\section{(iD)}

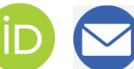

Анотація. Актуальною є проблема підготовки педагогічних кадрів до управління закладами позашкільної освіти з огляду на інтегративні стратегії розвитку освіти загалом, сучасні освітні ресорми, оновлені функції закладів позашкільної освіти в умовах диджиталізації освітнього середовища, технологізації освітньої діяльності, оновлення форм організації освітнього процесу, розвитку партнерства, створення педагогічних інновацій та їх упровадження в діяльність закладів позашкільної освіти. Всеукраїнська науковопрактична конференція «Позашкільна освіта у викликах сучасності: досягнення та вектори розвитку» дала змогу з'ясувати вектори розвитку позашкільної освіти та актуалізувати освітні тренди сучасності, серед яких - компетентнісний підхід в умовах сучасної позашкільної освіти; діяльність закладів позашкільної освіти в умовах адміністративно-територіальної реформи; профресійний розвиток і розвиток професійних 
компетентностей педагогічних працівників закладів позашкільної освіти; патріотичне виховання в сучасній позашкільній освіті; створення безпечного освітнього середовища в закладі позашкільної освіти; проєктна діяльність як механізм інновачійного розвитку позашкільної освіти; сучасні практики залучення дітей та молоді з особливими освітніми потребами до позашкільної освіти; педагогіка партнерства та співпраця в закладах позашкільної освіти; організація змішаного навчання в системі позашкільної освіти в умовах пандемії.

Ключові слова: позашкільна освіта; професійна компетентність педагогічних працівників; професійний розвиток педагогічних працівників; управління закладами позашкільної освіти; патріотичне виховання; безпечне освітнє середовище; інклюзивна освіта; проєктна діяльність; педагогіка партнерства; змішане навчання в умовах пандемії і диджиталізація.

Сучасні виклики, які постали перед людством в умовах карантинних обмежень, загострили наявні проблеми в суспільстві. Педагогічні працівники закладів позашкільної освіти стикаються 3 новими вимогами, згідно з якими освітяни повинні мати не лише ґрунтовні знання й уміння, а й виявляти такі якості особистості, як стресостійкість, гнучкість, мобільність, критичне мислення, готовність до інноваційної діяльності, варіативної реалізації змісту з урахуванням типів закладів освіти, можливостей педагогічних колективів тощо.

Актуальною сьогодні стає і потреба модернізації змісту позашкільної освіти, яка зокрема зумовлена і впровадженням інтеграційних процесів, що не лише стали пріоритетним напрямом загального розвитку, але й набули характеру конкретного шляху реалізації завдань, спрямованих на застосування в освіті фундаментальних принципів: від формування повної картини світу, планетарного мислення, уміння об'єднати в єдину цілісну систему вузькі галузеві проблеми до національної спрямованості освіти. Це передбачає інтеграцію освіти з національною історією, традиціями, українською культурою, а також відкритість освіти та її імплементацію у світовий освітній простір.

У Стратегії розвитку позашкільної освіти наголошено на необхідності забезпечувати розвиток професійної компетентності педагогічних працівників. У документі одним із стратегічних векторів названо управлінський вектор розвитку позашкільної освіти. «Активізація державно-громадського управління позашкільною освітою, закладами позашкільної освіти, удосконалення управлінської вертикалі і горизонталі у сфері позашкільної освіти» (Биковська, 2018, с. 67) - поставлені сьогодні важливі цілі, що є пріоритетними. Удосконалення планування, організації, мотивації і контролю в процесі управління закладами позашкільної освіти потребує застосування сучасних підходів до підвищення кваліфікації керівників закладів позашкільної освіти, враховуючи специфіку організації їх діяльності з дорослими як учнями. Отже, навчання має бути персоніфікованим, мати обґрунтовану практичну спрямованість, особистісний сенс розвитку професіоналізму й духовної зрілості.

Сучасна соціокультурна ситуація, у якій відбувається становлення особистості, зокрема молодого покоління, утворює суперечливе виховне середовище, що одночасно прискорює процес набуття життєвих навичок і ускладнює його в силу розмивання усталених життєвих орієнтирів, часткової деградації системи моральних і духовних цінностей. Це пояснюється насамперед зниженням рівня життя в Україні, відсутністю соціальної захищеності, явним і прихованим безробіттям, інфляцією, невизначеністю та асоціальними явищами: порушення норм моралі та правил людського співжиття, правопорушення, злочини.

Зважаючи на це, роль закладів позашкільної освіти набуває нового сенсу, адже в них відповідно до декларованого державою призначення можуть забезпечуватися варіативні аспекти виховання: від засвоєння молоддю моральної культури як особистісної ціннісної орієнтації до визначення життєвої позиції стосовно реалізації власного інтересу і вибору в різних видах творчої та освітньої діяльності.

На сучасному етапі важливими є вдосконалення та осучаснення змісту позашкільної освіти через диджиталізацію освітнього середовища, технологізацію освітньої діяльності, оновлення форм організації освітнього процесу, розвиток партнерства, створення педагогічних інновацій та їх активне впровадження в діяльність закладів позашкільної освіти.

Тож у контексті сучасних освітніх актуалітетів і викликів позашкільної освіти, відповідно до плану заходів Національної академії педагогічних наук України, було проведено Всеукраїнську науково-практичну конференцію "Позашкільна освіта у викликах сучасності: досягнення та вектори розвитку» (22 квітня 2021 р. у режимі онлайн). Усеукраїнський захід об'єднав представ- 


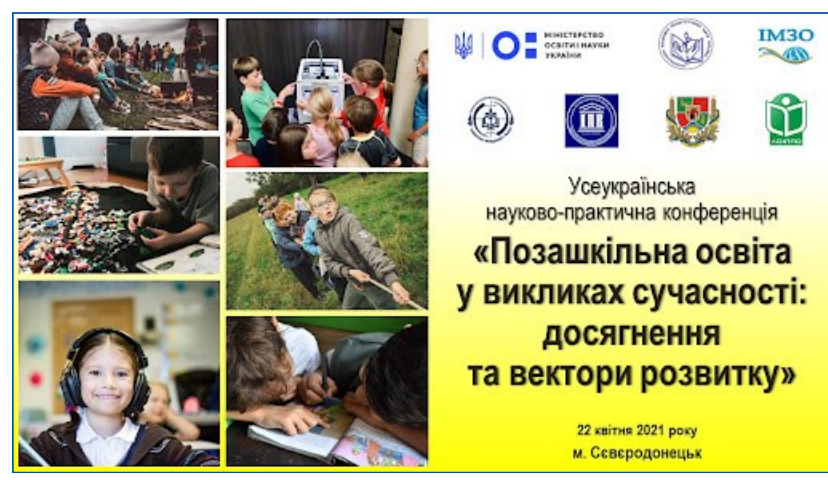

ників органів державної влади, науковців, практиків навколо важливих питань розвитку позашкільної освіти. Учасники конференції обговорили важливі питання щодо функціонування і розвитку закладів позашкільної освіти, особливо в умовах пандемії, впровадження сучасних наукових підходів та інноваційних практик в освітній процес; ознайомилися 3 досягненнями різних регіонів; збагатили власний досвід та розширили партнерські професійні контакти.

Серед тематичних напрямів роботи конференції - сучасні концепти позашкільної освіти, як-от:

1. Актуальні тенденції розвитку позашкільної освіти.

2. Компетентнісний підхід як основа для оновлення змісту сучасної позашкільної освіти.

3. Діяльність закладів позашкільної освіти в умовах адміністративно-територіальної реформи.

4. Розвиток професійних компетентностей педагога закладу позашкільної освіти.

5. Напрями патріотичного виховання в сучасній позашкільній освіті.

6. Створення безпечного та здорового освітнього середовища в закладі позашкільної освіти.

7. Проєктна діяльність як механізм інноваційного розвитку позашкільної освіти.

8. Сучасні практики залучення дітей та молоді з особливими освітніми потребами до позашкільної освіти.

9. Педагогіка партнерства та співпраця в закладах позашкільної освіти.

10. Організація змішаного навчання в системі позашкільної освіти в умовах пандемії.

Організаторами та співорганізаторами конференції виступили: Міністерство освіти і науки України, Національна академія педагогічних наук України, ДзВО «Університет менеджменту освіти» НАПН України (кафедра філософії і освіти дорослих Центрального інституту післядипломної освіти), Інститут проблем виховання НАПН України (лабораторія позашкільної освіти), Національний еколого-натуралістичний центр учнівської молоді МОН України, Український державний центр національно-патріотичного виховання, краєзнавства і туризму учнівської молоді, Національний педагогічний університет імені М.П. Драгоманова (кафедра позашкільної освіти), ДНУ «/нститут модернізації змісту освіти» (відділ наукового та навчально-методичного забезпечення змісту позашкільної освіти та виховної роботи), Департамент освіти і науки Луганської обласної державної адміністрації, Луганський обласний інститут післядипломної педагогічної освіти, Національний центр «Мала академія наук України», Міжнародна асоціація позашкільної освіти, обласні заклади позашкільної освіти Луганської області.

Серед учасників конференції - науковопедагогічні та педагогічні працівники закладів вищої та післядипломної освіти, науковці, керівники та педагоги закладів позашкільної освіти, фахівці центрів професійного розвитку педагогічних працівників, фахівці органів управління освітою, представники громадських організацій (усього понад 200 осіб). Географія заходу представлена різними областями України (Донецька, Дніпропетровська, Закарпатська, Івано-Франківська, Кіровоградська, Київська, Луганська, Львівська, Миколаївська, Одеська, Полтавська, Рівненська, Сумська, Харківська, Хмельницька, Чернівецька та Чернігівська).

Модератором заходу виступила Ольга Касьянова, заступник директора з наукової роботи Луганського обласного інституту післядипломної педагогічної освіти, кандидат педагогічних наук, доцент, яка актуалізувала тенденції позашкільної освіти в Україні: розвиток забезпечення якості позашкільної освіти, доступність, розширення функцій закладів позашкільної освіти, оновлення змісту й методик з урахуванням компетентнісного підходу. Водночас в умовах реформи «Нова українська школа» на позашкільну освіту покла-

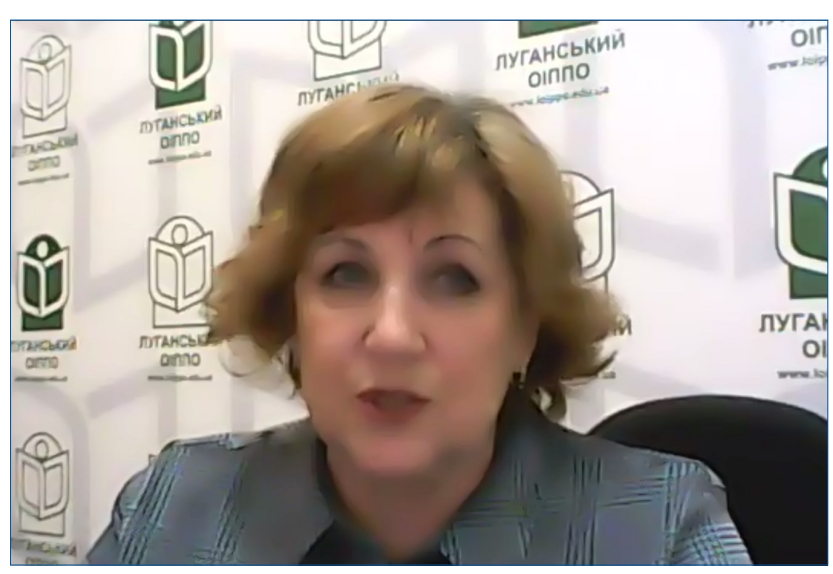


дено суміжні завдання, що потребують оновлення змісту, переосмислення форм, технологій роботи, модернізації середовища та підготовки педагогічних працівників.

Особливо важливим для закладів позашкільної освіти Луганської області $\epsilon$ національнопатріотичне виховання дітей та молоді, адже вже восьмий рік не припиняється військовий конфлікт. Ольга Касьянова закцентувала, що впродовж цих років «ми намагаємось об'єднати зусилля органів державної влади, учених, практиків різних регіонів України навколо проблеми національно-патріотичного виховання, об'єднати всіх, кому не байдужа доля України, та обговорити на заходах різного рівня шляхи його реалізації 3 урахуванням соціокультурних особливостей і віднайти відповіді на запитання: як виховувати сучасних дітей, щоб у майбутньому вони стали свідомими та гідними громадянами».

До учасників звернувся Василь М'ягкоход, завідувач відділу позашкільної, спеціальної освіти, закладів та установ обласної комунальної власності Департаменту освіти і науки Луганської облдержадміністрації. У привітальному слові він наголосив, що в умовах децентралізації та формування нових адміністративно-територіальних одиниць у Луганській області постає завдання консолідація дій органів державної влади та місцевого самоврядування, закладів позашкільної освіти та громадськості з метою вироблення конструктивних рішень щодо створення ефективної мережі, забезпечення функціонування позашкільних закладів та створення умов для їх роботи в нових адміністративно-територіальних одиницях.

Олена Биковська, завідувач кафедри позашкільної освіти Національного педагогічного університету імені М.П. Драгоманова, президент Міжнародної асоціації позашкільної освіти, доктор педагогічних наук, професор, заслужений діяч науки і техніки України, у своїй доповіді «Підготовка кадрів позашкільної освіти» зосередила увагу на питанні підготовки кадрів позашкільної освіти в закладах вищої освіти, що є гарантією впровадження змін у галузі. У цьому напрямі важливими є зміни в нормативно-правових актах, які стосуються введення до переліку галузей знань і спеціальностей, за якими здійснюється підготовка здобувачів вищої освіти, окремої спеціальності «Позашкільна освіта», а також піднесення престижу професії педагогічного працівника закладу позашкільної освіти шляхом запровадження нових моральних та матеріаль-

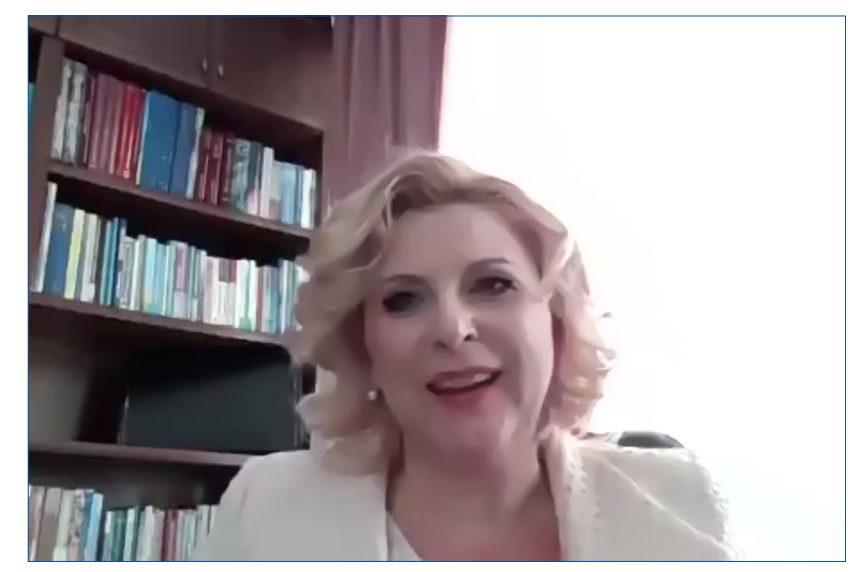

них стимулів, просування оплати праці педагогічних працівників по Єдиній тарифній сітці.

Від Національного еколого-натуралістичного центру учнівської молоді виступив Володимир Вербицький, директор, доктор педагогічних наук, професор, який у своїй доповіді «Організаційнопедагогічні основи діяльності позашкільного закладу освіти на сучасному етапі розвитку» акцентував на впровадженні сучасних підходів та ефективних технологій в освітньому процесі позашкільної освіти, зміцненні зв'язків школи і позашкілля задля спільного проведення експериментальних робіт та формування дослідницьких навичок вихованців, упровадженні дистанційних технологій в умовах карантинних обмежень.

Протягом 30 років незалежності України вчені активно досліджували проблему національнопатріотичного виховання: створювалася концепція військово-патріотичного виховання, розроблялася національна ідея в становленні громадянина-патріота України, проводилися наукові дослідження різних аспектів цієї проблематики (Просіна, 2016). Але, незважаючи на таку масштабну наукову роботу, не вдалося запобігти національній трагедії, що сталася на Сході країни. На гострих питаннях специфіки патріотичного виховання в сучасних умовах зупинився у своєму виступі Сергій Неділько, директор Українського державного центру національно-патріотичного виховання, краєзнавства і туризму учнівської молоді. Він розкрив основні напрями патріотичного виховання в сучасній позашкільній освіті, відзначив важливе місце в системі освіти України та координації національно-патріотичного виховання закладів туристсько-краєзнавчого напряму.

Ольга Флярковська начальник відділу наукового та навчально-методичного забезпечення змісту позашкільної освіти та виховної роботи ДНУ «Інститут модернізації змісту освіти» $\mathrm{MOH}$ України, кандидат педагогічних наук, доцент, у 


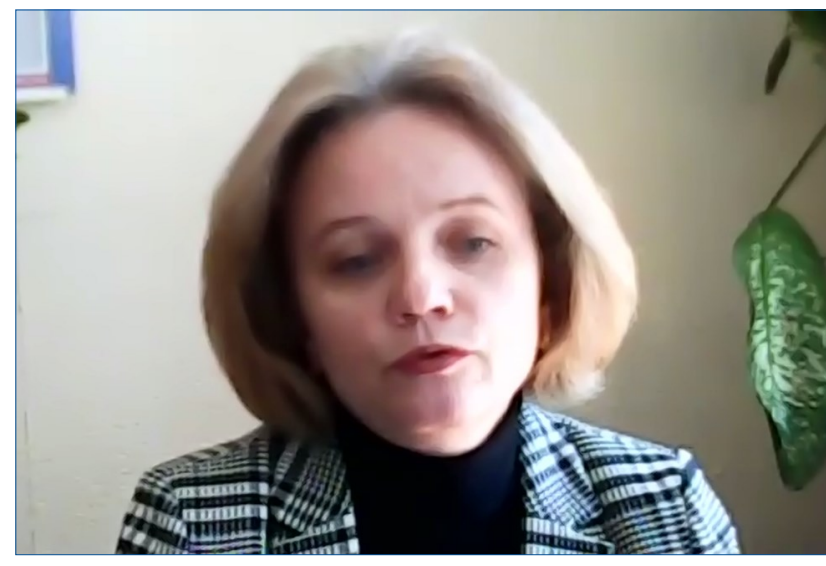

виступі «Позашкільна освіта в системі освітнього простору» приділила увагу питанням розробки сучасного змісту позашкільної освіти, який має бути націлений на створення умов для особистісного розвитку дітей та молоді, зміцнення їх духовного, інтелектуального й фізичного здоров'я, професійного самовизначення і творчої самореалізації. Не можна також недооцінювати значення позашкільної освіти для забезпечення емоційного благополуччя дітей та молоді, зміцнення їх психічного і фізичного здоров'я, особливо в умовах кризових світових явищ.

Вчені Державного закладу вищої освіти «Університет менеджменту освіти» НАПН України презентували теоретико-практичні засади наукових пошуків.

Серед доповідачів - Ольга Просіна, завідувач кафедри філософії і освіти дорослих Центрального інституту післядипломної освіти ДЗВО «Університет менеджменту освіти», кандидат педагогічних наук, доцент. У своїй доповіді «Управління закладом позашкільної освіти: сучасні тренди, співпраця, проєкти» представила:

- цифровий проєкт «Інтерактивний кейс для позашкільників «Навчаймося разом! Творчі знахідки викладачів кафедри філософії і освіти

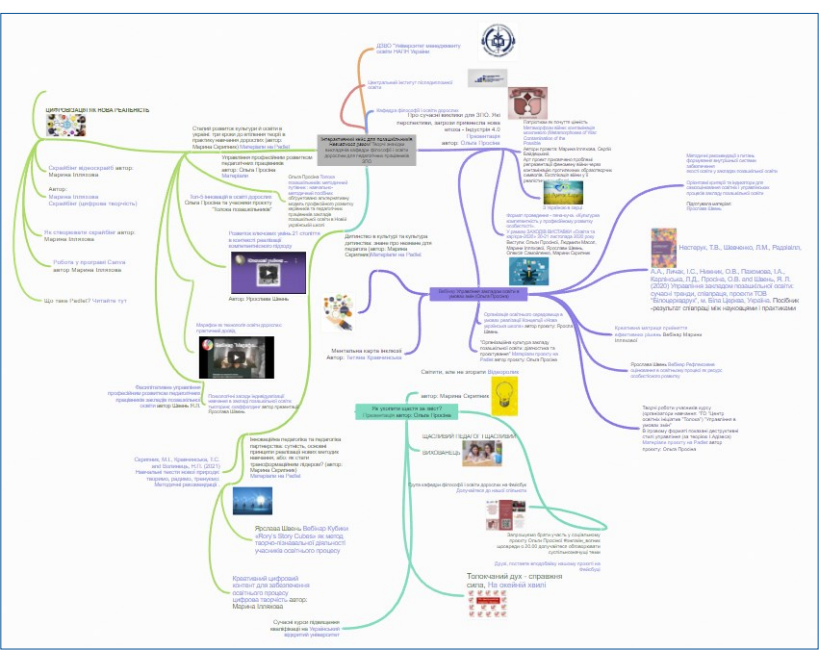

дорослих для педагогічних працівників закладів позашкільної освіти» (керівник проєкту - доц. О.В. Просіна; учасники - доц. М.В. Ілляхова, доц. Т.С. Кравчинська, доц. М.І. Скрипник, доц. Я.Л. Швень);

- посібник «Управління закладом позашкільної освіти: сучасні тренди, співпраця, проєкти» (авторський колектив: О.В. Просіна., Я.Л. Швень, Т.В. Нестерук, Л.М. Шевченко, А.А. Радзівілл, І.С. Личак, О.В. Нижник, І.А. Пахомова, Л.Д. Карлінська);

- методичні рекомендації «Навчальні тексти нової природи: творимо, радимо, тренуємо» (М.І. Скрипник, Т.С. Кравчинська, Н.П. Волинець).

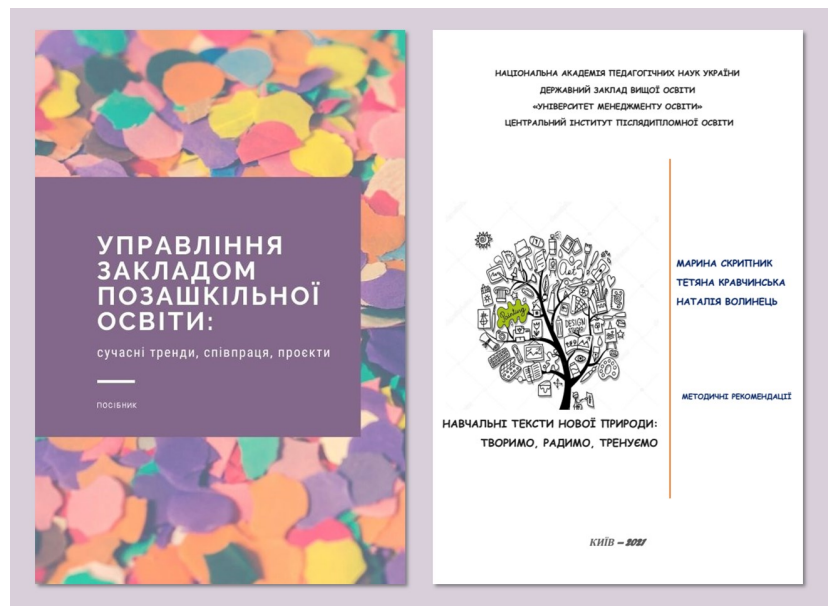

Марина Ілляхова, кандидат філософських наук, доцент, доцент кафедри філософії і освіти Центрального інституту післядипломної освіти ДЗВО «Університет менеджменту освіти» виступила із доповіддю «Алгоритм розвитку професійної креативності педагога закладу позашкільної освіти». Доповідачка зазначила, що професійна креативність педагога позашкільної освіти $\epsilon$ системною, багатофакторною, інтегративною єдністю когнітивних знань, операційних умінь, праксеологічних навичок, ціннісних орієнтацій, акмеологічних настанов фахівця, що уможливлюють його ефективну діяльність, забезпечують систематичне, інноваційне оновлення змісту і методів освітнього процесу, реалізують потенціал діагностики та аналізу освітньої діяльності, формують навички до самоактуалізації, самоорганізації, самодетермінації, розвивають потенціал латерального, гнучкого, інноваційного мислення, соціальної та професійної мобільності, актуалізують потребу у самоосвіті, умінні реагувати на непередбачувані, змінні умови професійної діяльності й володіти динамікою власних життєвопрофесійних можливостей. Гармонійне співвідношення складників, компонентів і професійних 
якостей педагога формує вищий рівень розвитку його професійної креативності (Ілляхова, 2019).

Ярослава Швень, кандидат психологічних наук, доцент, доцент кафедри філософії і освіти Центрального інституту післядипломної освіти ДЗВО «Університет менеджменту освіти», у виступі «Психологічні засади індивідуалізації навчання в закладі позашкільної освіти: тьюторінг, скаффолдинг» висвітлила сучасні інноваційні підходи до психологічного супроводу освітнього процесу в закладі позашкільної освіти, актуальність індивідуалізації навчання як освітнього тренду сучасності для всебічного особистісного розвитку гуртківців в умовах закладу позашкільної освіти, що є вихідним для якісного тьюторінгу в освітньому процесі (Швень, 2021).

Надзвичайно важливу роль у розробці та проведенні наукових досліджень і створенні за їх результатами сучасних науково-методичних матеріалів для позашкільної освіти відіграє Інститут проблем виховання НАПН України, який представив Валерій Мачуський, завідувач лабораторії позашкільної освіти Інституту проблем виховання НАПН України, кандидат педагогічних наук, старший науковий співробітник. У своєму виступі «Про стан освітнього процесу в закладах позашкільної освіти» він зосередив увагу на питаннях створення нового змісту, розробки нових навчальних програм для позашкільної освіти, організації освітнього процесу з використанням технологій дистанційного навчання, формування компетентностей та набутті вихованцями знань і вмінь з допрофесійної підготовки тощо.

Робота Всеукраїнської науково-практичної конференції продовжилася на п'яти секціях:

- «Національно-патріотичне виховання учнівської молоді в закладі позашкільної освіти»;

- «Простір позашкілля для дітей з особливими освітніми потребами»;

- «Створення сучасного змісту позашкільної освіти на компетентнісних засадах»;

- «Системний підхід до формування дослідницьких здібностей і цілеспрямованої діяльності вихованців Малої академії наук України»;

- «Організація освітнього процесу в закладах позашкільної освіти з використанням дистанційних технологій».

Учасники конференції у своїх виступах зробили наголос на тому, що заклади позашкільної освіти в умовах реформування та автономії отримали більшої самостійності у прийнятті рішень внутрішнього значення, пошуку шляхів

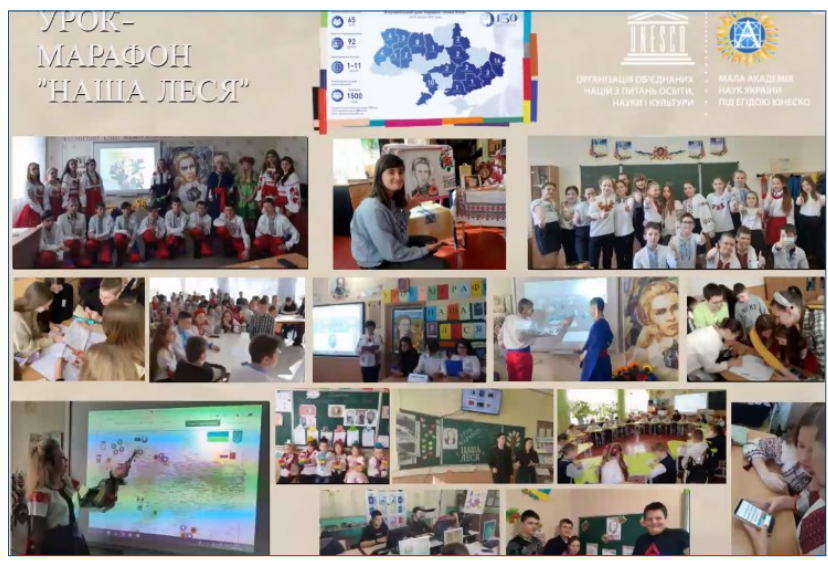

оптимального застосування ресурсів і технологій, створення бажаного інноваційного освітнього простору. Відповідно це потребує підготовки керівників, набуття нових та вдосконалення наявних компетентностей стратегічного управління, опановування інноваційних технологій управління фінансовими, господарськими, навчальнометодичними, кадровими справами закладів освіти. Нові правила підвищення кваліфікації, закріплені сьогодні на законодавчому рівні, забезпечили умови для вибору педагогами позашкільної освіти напряму професійного вдосконалення, форми навчання та суб'єкта, який надає послуги, що забезпечить неперервний професійний розвиток, вибудовування індивідуальної траєкторії професійного розвитку, що суттєво вплине на якість позашкільної освіти.

Репрезентація власних напрацювань та обмін досвідом учасників заходу $€$ важливим для трансформацій у сфері позашкільної освіти, запровадженні в освітній процес компетентнісного, особистісно орієнтованого, діяльнісного підходів до навчання дітей, інклюзивної освіти, нових освітніх технологій, осучаснення освітнього простору та наповнення його сучасним обладнанням організації освітнього процесу в умовах дистанційного навчання, опанування цифрових сервісів та онлайн-платформ.

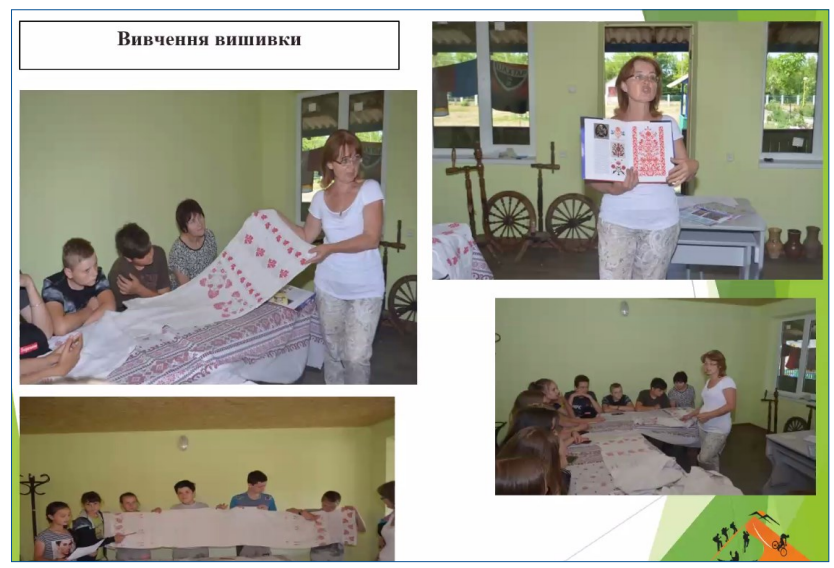


Отже, в контексті реалізації державної політики щодо розвитку позашкільної освіти та вдосконалення ії якості та доступності важливими видаються такі пріоритетні напрями:

- створення системи ефективної взаємодії між місцевою владою, територіальними громадами, батьківською громадськістю та закладами позашкільної освіти з питань освітньої діяльності;

- збереження і розвиток мережі закладів позашкільної освіти та збільшення охоплення учнів позашкільною освітою, організація роботи гуртків, секцій, філій обласної МАН України у новостворених громадах за різними напрямами;

- продовження роботи з осучаснення змісту позашкільної освіти через розроблення освітніх та навчальних програм, що відповідатимуть сучасним потребам і спрямовані на розвиток компетентностей та творчих здібностей вихованців;

- розбудова внутрішньої системи забезпечення якості освіти у закладах позашкільної освіти;

- спрямування зусиль педагогів позашкільної освіти на запровадження в освітній процес інноваційних педагогічних технологій, що ґрунтуються на засадах компетентнісного підходу;

- упровадження в освітній процес закладів позашкільної освіти моделі та технології дистанційного навчання як вимоги сучасності;

- усебічна підтримка та спрямування зусиль щодо реалізації прав дітей з особливими освітніми потребами на здобуття позашкільної освіти;

- розширення можливостей соціального партнерства, співпраці з сім'єю, активне залучення міжнародних, державних фондів та організацій, співпраці з молодіжними й дитячими громадськими організаціями;

- активізація роботи з обдарованими й талановитими дітьми, створення умови для розвитку їхніх творчих здібностей у Луганській малій академії наук через відкриття STEM-центру;

- забезпечення розвитку профільного навчання в закладах позашкільної освіти для формування позитивної мотивації вивчення та вибору майбутньої професії вихованців;

- безперервний професійний розвиток керівників та педагогічних працівників закладів позашкільної освіти з метою набуття нових та вдосконалення раніше набутих професійних та загальних компетентностей.

\section{СПИСОК ВИКОРИСТАНИХ ДЖЕРЕЛ}

Биковська, О.В. (ред.). (2018). Стратегія розвитку позашкільної освіти. Київ: ІВЦ АЛКОН. https:// bit.ly/3ICzAW5
Державна наукова установа «Інститут модернізації змісту освіти». (2021). Реформуємо, модернізуємо, вдосконалюємо позашкільну освіту. https:// bit.ly/3DDX97d

Ілляхова, М.В. (2019). Креативність і творчість: дефініції понять. Актуальні питання гуманітарних наук, (23), 95-100. http://www.aphn-journal.in.ua/ archive/23_2019/part_2/20.pdf

Кафедра філософії і освіти дорослих Центрального інституту післядипломної педагогічної освіти ДЗВО «Університет менеджменту освіти». (2020). Інтерактивний кейс для позашкільників «Навчаймося разом! Творчі знахідки викладачів кафедри філософої освіти і освіти дорослих для педагогічних працівників закладів позашкільної освіти». https:// bit.ly/3BEfUqq

Луганський обласний інститут післядипломної педагогічної освіти. (2021). Відбулась Усеукраїнська науково-практична конференція "Позашкільна освіта у викликах сучасності: досягнення та вектори розвитку». https://bit.ly/3oZeROp

Луганський обласний інститут післядипломної педагогічної освіти. (2021). Матеріали Всеукраїнської науково-практичної онлайн-конферениії «Позашкільна освіта у викликах сучасності: досягнення ma вектори розвитку» (22.04.2021). https://bit.ly/3DFwJls

Просіна, О.В. (2016). Специфіка патріотичного виховання учнів в умовах Східного пограниччя України. Теоретико-методичні проблеми виховання дітей mа учнівської молоді, (20), 151-163. http:// nbuv.gov.ua/UJRN/Tmpvd_2016_20(2)_16

Просіна, О.В. (2017). Закономірності сучасного освітнього менеджменту в управлінні системою виховної діяльності позашкільного навчального закладу. Теоретико-методичні проблеми виховання дітей та учнівської молоді, (21), 178-187. http:// nbuv.gov.ua/UJRN/Tmpvd_2017_21(2)_18

Просіна, О.В. (2018). Толока позашкільників: методич ний путівник : навчально-методичний посібник (Т.М. Сорочан, В.В. Сидоренко, наук. ред.). Київ: СПД Резников В.C. https://lib.iitta.gov.ua/720720/

Просіна, О.В., \& Онуфрієва, О.Л. (2021). Маркетингова компетентність керівників гуртків та ії розвиток у межах демократично-перетворювальної технології управління системою освітньої діяльності. Науковий часопис Національного педагогічного університету імені М.П. Драгоманова. Серія 5 «Педагогічні науки: реалії та перспективи», (79), 68-72. https:// doi.org/10.31392/NPU-nc.series5.2021.79.2.14

Просіна, О.В., \& Швень, Я.Л. (2021). Нелінійні актуалітети трансформаційного управління закладами позашкільної освіти: теоретичний опис. Київ: ЦІПО.

Просіна, О.В., \& Швень, Я.Л. (наук. ред.). (2020). Управління закладом позашкільної освіти: сучасні тренди, співпрачя, проєкти : посібник. Біла Церква: ТОВ «Білоцерківдрук». https://lib.iitta.gov.ua/724183/

Скрипник, М.І., Кравчинська, Т.С., \& Волинець, Н.П. (2021). Навчальні тексти нової природи: творимо, радимо, тренуємо : методичні рекомендації. Київ: ЦІПО. https://lib.iitta.gov.ua/723446/

Швень, Я. (2021). Психологічні засади індивідуалізації навчання в закладі позашкільної освіти: тьюторінг, скаффролдинг [Відео]. YouTube. https:// youtu.be/jsT8_iNPD-k 


\section{VECTORS OF OUT-OF-SCHOOL EDUCATION DEVELOPMENT AS MODERN EDUCATIONAL TRENDS}

Based on the materials of the All-Ukrainian Scientific and Practical Conference "Out-of-School Education in the Challenges of Today: Achievements and Development Vectors", April 22, 2021, in accordance with the Action Plan of the National Academy of Educational Sciences of Ukraine (Devoted to the 30th Anniversary of Ukraine' Independence)

Olha Prosina

PhD in Pedagogy, Associate Professor, Head of the Department of Philosophy and Adult Education of the Central Institute of Postgraduate Education, State Higher Education Institution "University of

Educational Management", National Academy of Educational Sciences of Ukraine; Head, NGO "Center for Educational Initiatives "Toloka", Kyiv, Ukraine Olha Kasianova

PhD in Pedagogy, Associate Professor, Deputy Director for Scientific Work, Luhansk Regional In-Service Teacher Training Institute, Sievierodonetsk, Ukraine Yaroslava Shven

PhD in Psychology, Associate Professor, Associate Professor of the Department of Philosophy and Adult Education of the Central Institute of Postgraduate Education, State Higher Education Institution

"University of Educational Management", National Academy of Educational Sciences of Ukraine; Member, National Psychological Association, Kyiv, Ukraine

Abstract. The problem of teacher training to manage the out-of-school education institutions given the integrative strategies of education development in general, current educational reforms, updated functions of the out-of-school education institutions in the educational environment digitalization, technologization of educational activities, renewing the educational process forms, developing partnership, creating pedagogical innovations and their implementation in the out-of-school education institutions is relevant. The All-Ukrainian Scientific and Practical Conference "Out-of-School Education in the Challenges of Today: Achievements and Development Vectors" allowed to determine the vectors of out-of-school education development and actualize modern educational trends, i.e.: competence approach in modern out-of-school education; out-of-school education institutions functioning under the administrative and territorial reform; teaching staff professional development and development of professional competences; patriotic education in modern out-of-school education; creating a safe learning environment in an out-ofschool education institution; project-based activity as a mechanism of out-of-school education innovative development; modern practices of involving children and youth with special educational needs in out-of-school education; pedagogy of partnership and collaboration in out-of-school education institutions; organization of blended learning in the out-ofschool education system during a pandemic.

Keywords: out-of-school education; teachers' professional competence; teachers' professional development; managing out-of-school education institutions; patriotic education; safe learning environment; inclusive education; project-based activity; pedagogy of partnership; blended learning during a pandemic and digitalization.

Дата публікації: 24 вересня 2021 р. 